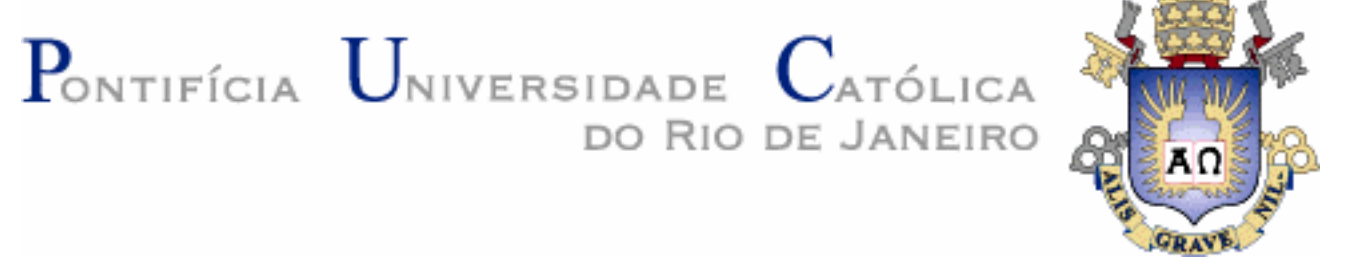

ANTÔNIO JORGE GOMES ABELÉM

\title{
Difusão Seletiva em Inter-Redes IP Baseadas em Redes Ópticas
}

TESE DE DOUTORADO

DEPARTAMENTO DE INFORMÁTICA

Programa de Pós-Graduação em Informática 